\title{
Meta-Analysis the Association between Chronic Obstructive Pulmonary Disease Comorbidity and COVID-19 Mortality
}

\author{
Pamogsa Ratri Adha Daniyar'), Agus Kristiyanto²), Setyo Sri Rahardjo') \\ 1)Masters Program in Public Health, Universitas Sebelas Maret \\ 2)Faculty of Sport Education, Universitas Sebelas Maret
}

\section{ABSTRACT}

Background: COVID-19 is an infectious disease that hit the world community at the end of 2019. The risk of death from COVID-19 is highly dependent on age and previous health conditions. COVID-19 severe and critical symptoms are more commonly found in older patients and patients who have chronic comorbidities such as cardiovascular disease, hypertension, diabetes, including COPD. This study aims to determine the relationship between COPD and mortality of COVID-19 patients in hospitals.

Subjects and Method: This a meta-analysis study using the PRISMA flowchart guidelines. The article search process was carried out between 2020-2021 using databases from PubMed, Google Scholar, Science Direct, BMJ Garuda, SINTA, and National Library. Based on the database, there were 9 articles that met the inclusion criteria. The analysis was carried out using RevMan 5.3 software.

Results: A total of 9 articles reviewed in the meta-analysis showed that comorbid COPD had a statistically significant association with hospital mortality of COVID-19 patients $(\mathrm{aOR}=$ $1.51 ; 95 \% \mathrm{CI}=1.21$ to $1.9 ; \mathrm{p}<0.001$ ).

Conclusion: COPD comorbidities have an increased risk of dying of COVID-19 patients in hospital.

Keywords: CPOD, COVID-19, death, metaanalysis

\section{Correspondence:}

Pamogsa Ratri Adha Daniyar. Masters Program in Public Health, Universitas Sebelas Maret. Jl. Ir. Sutami 36A, Surakarta 57126, Central Java. Email: pamogsadaniyar@gmail.com. Mobile: +62 852-9060-1552.

\section{Cite this as:}

Daniyar PRA, Kristiyanto A, Rahardjo SS (2021). Meta-Analysis the Association between Chronic Obstructive Pulmonary Disease Comorbidity and COVID-19 Mortality. J Epidemiol Public Health. 06(02): 222-231. https://doi.org/10.26911/jepublichealth.2021.06.02.09. (c) (7)(2) Jo Journal of Maternal and Child Health is licensed under a Creative Commons

\section{BACKGROUND}

In late 2019 to early 2020, the world was shocked by the emergence of a new type of corona virus called Severe Acute Respiratory Syndrome Coronavirus 2 (SARS-CoV2). The disease is known as Coronavirus Disease 2019 (COVID-19). To date, there are around 200 countries that have been infected with the corona virus, and from July 1, 2020 to July 2021, the virus that has spread has resulted in more than 180,000 million cases (WHO, 2020). This virus is confirmed to have pneumonia transmission that can be transmitted from one human to another, besides that the spread and transmission of this virus is relatively fast and research on COVID-19 is still continuing (Relman, 2020).

Respiratory disease is a clinical manifestation that often occurs in patients with COVID-19. Compared to patients without comorbidities, patients with comorbidities had a significantly increased Case Fatality Rate (CFR) of $10.5 \%$ for Cardiovascular Disease (CVD), $7.3 \%$ for Diabetes Mellitus (DM), 6.3\% for COPD, 6\% for hypertension and $5.6 \%$ for cancer. (Alemzadeh, 2020) 
Some of the participant's diseases are a big risk for the death of COVID-19 patients, one of which is Chronic Obstructive Pulmonary Disease (COPD). COPD is one of the public health problems caused by the epidemiological transition in Indonesia. COPD can also be influenced by demographic factors, behavioral factors, environmental factors, and life expectancy in the community (Hidayani, 2020; RI, 2008).

In the management of COVID-19 patients with COPD, there are several opinions about the provision of treatment, such as through a nebulizer during the pandemic. The use of inhaler devices is a safer method and is recommended, because non-invasive mechanical ventilators can increase the risk of contamination, they are not included among routine care recommendations for patients with COPD (Viktorova et al., 2020).

Based on the number of cases of COVID-19 that afflicts patients with COPD and the need for proper prevention and treatment, the researchers are interested in conducting a meta-analysis of the relationship between COPD comorbidities and mortality of COVID-19 patients in hospitals. This study aims to determine the relationship between COPD and mortality of COVID-19 patients in hospital, with a metaanalysis of primary studies that have been carried out previously.

\section{SUBJECTS AND METHOD}

\section{Study Design}

This study was conducted using a metaanalysis study design with PRISMA flow diagram guidelines. Article searches were conducted using the following databases: PubMed, Google Scholar, Science Direct, BMJ Garuda, SINTA, and National Library. Some of the keywords used were: "COVID19" OR "SARS-CoV-2" AND "Chronic obstructive pulmonary disease" OR "Chronic pulmonary disease" AND "death in hospital” OR mortality OR fatality OR death.

\section{Inclusion Criteria}

The inclusion criteria for this research article are full paper cohort study articles, articles using English and Indonesian, using the Odds Ratio relationship measure, COVID-19 patient subjects, patient mortality outcomes.

\section{Exclusion Criteria}

The exclusion criteria for this research article are articles that do not use English or Indonesian, RCT studies, not multivariate analysis studies.

\section{Operational Definition}

Articles included in the study were PICOadjusted. The search for articles was carried out by considering the eligibility criteria defined using the PICO model. The research population is COVID-19 patients, using COPD intervention and non-COPD controls and the outcome is death.

\section{COPD (Chronic Obstructive Pulmo-} nary Disease) is a chronic inflammation of the lungs that causes airflow obstruction in the airways and occurs in the long term which is recorded in medical records with continuous data.

COVID-19 patient mortality is the number of deaths in COVID-19 patients recorded in medical records on a categorical scale.

\section{Instrument}

The research is guided by the PRISMA flow diagram and the assessment of the quality of research articles using the Critical Appraisal Checklist for Cohort Study tools (CEBM, 2014).

\section{Data Analysis}

The research data were analyzed using the RevMan 5.3 application, to calculate the effect size and heterogeneity of the study. The results of data processing are presented in the form of forest plots and funnel plots. 


\section{RESULTS}

The article review process using the PRISMA flowchart can be seen in Figure 1.
The total articles obtained were 10 articles spread over 3 continents, namely Asia, Europe and America.

\begin{tabular}{|c|c|}
\hline $\begin{array}{l}\text { Articles identified through database } \\
\text { search }(n=524)\end{array}$ & Remove duplicate articles $(\mathrm{n}=28)$ \\
\hline$\downarrow$ & Issued article $(\mathrm{n}=251)$ \\
\hline Filtered articles $(n=496)$ & $\begin{array}{l}\text { 1. Irrelevant title }=128 \\
\text { 2. Article not full text }=115\end{array}$ \\
\hline & \\
\hline $\begin{array}{l}\text { Full text articles that are considered } \\
\text { eligible }(n=245)\end{array}$ & $\begin{array}{l}\text { Full text articles issued, with reasons }(\mathrm{n}= \\
235)\end{array}$ \\
\hline$\downarrow$ & $\begin{array}{l}\text { 1. Articles are not multivariate analysis }= \\
138\end{array}$ \\
\hline $\begin{array}{l}\text { Articles included in the meta-analysis } \\
\text { quantitative synthesis }(\mathrm{n}=9)\end{array}$ & $\begin{array}{l}\text { 2. Topics not according to inclusion }=32 \\
\text { 3. Outcome not death }=52 \\
\text { 4. The size of the relationship is not } \mathrm{RR} \\
\text { or } \mathrm{OR}=14\end{array}$ \\
\hline
\end{tabular}

Figure 1. PRISMA flowchart

1. The relationship between COPD and mortality of COVID-19 patients in hospital

Table 1 shows 9 cohort articles on the relationship of COPD with mortality of COVID19 patients in hospitals that meet qualitative and quantitative requirements.

\section{a. Forest plot}

Interpretation of the results of the metaanalysis process can be seen through the forest plot. Figure 2 shows that there is a statistically significant relationship between COPD comorbidities and hospital mortality for COVID-19 patients. COVID-19 patients with comorbid COPD had 1.51 times the risk of dying compared to patients without $\mathrm{COPD}(\mathrm{aOR}=1.51 ; 95 \% \mathrm{CI}=1.21$ to 1.9 ; $\mathrm{p}<0.001)$.

\begin{tabular}{|c|c|c|c|c|c|c|c|c|}
\hline \multirow{2}{*}{$\begin{array}{l}\text { Study or Subgroup } \\
\text { Borgne et. al. } 2021\end{array}$} & \multirow{2}{*}{$\begin{array}{r}\text { log[Odds Ratio] } \\
1.1442\end{array}$} & SE & Weight & $\begin{array}{l}\text { Odds Ratio } \\
\text { IV, Fixed, 95\% Cl }\end{array}$ & \multicolumn{4}{|c|}{$\begin{array}{c}\text { Odds Ratio } \\
\text { IV, Fixed, 95\% Cl }\end{array}$} \\
\hline & & 0.8195 & $1.9 \%$ & $3.14[0.63,15.65]$ & & & & \\
\hline Caliskan 2020 & 1.1672 & 0.4924 & $5.4 \%$ & $3.21[1.22,8.43]$ & & & & \\
\hline Cetinkal 2020 & -0.3011 & 0.4607 & $6.2 \%$ & $0.74[0.30,1.83]$ & & & & \\
\hline Chen et. al. 2020 & 0.5423 & 0.3906 & $8.6 \%$ & $1.72[0.80,3.70]$ & & & & \\
\hline Hobbs et. al 2020 & 0.4574 & 0.494 & $5.4 \%$ & $1.58[0.60,4.16]$ & & & & \\
\hline Hu et. al. 2020 & 0.8198 & 0.646 & $3.1 \%$ & $2.27[0.64,8.05]$ & & & & \\
\hline Magleby et. al 2020 & -0.4308 & 0.5301 & $4.7 \%$ & $0.65[0.23,1.84]$ & & & & \\
\hline Oh 2021 & 0.4447 & 0.1972 & $33.7 \%$ & $1.56[1.06,2.30]$ & & & 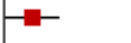 & \\
\hline Rosa et. al. 2021 & 0.392 & 0.2052 & $31.1 \%$ & $1.48[0.99,2.21]$ & & & $5-$ & \\
\hline Total $(95 \% \mathrm{Cl})$ & & & $100.0 \%$ & $1.51[1.21,1.90]$ & & & & \\
\hline $\begin{array}{l}\text { Heterogeneity: } \mathrm{Ch}^{2}= \\
\text { Test for overall effect: }\end{array}$ & $\begin{array}{l}8.63, \mathrm{df}=8(P=0.3 \\
Z=3.63(P=0.000\end{array}$ & $\begin{array}{l}37) ;\left.\right|^{2}=7 \\
\text { j3) }\end{array}$ & & & 0.01 & $0.1{ }^{1}$ & PPOK & 100 \\
\hline
\end{tabular}

Figure 2. Forest plot the relationship between COPD and mortality of COVID-19 patients in hospital 
Daniyar et al./ Chronic Obstructive Pulmonary Disease and COVID-19 Mortality

Table 1. Relationship of COPD with mortality of COVID-19 patients in hospital

\begin{tabular}{|c|c|c|c|c|c|c|c|c|}
\hline $\begin{array}{c}\text { Author } \\
\text { (year) }\end{array}$ & OR (CI) & Country & $\begin{array}{c}\text { Study } \\
\text { Design }\end{array}$ & Sample & $\mathbf{P}$ & $\mathbf{I}$ & $\mathbf{C}$ & $\mathbf{O}$ \\
\hline $\begin{array}{l}\text { Hu et. al., } \\
(2020)\end{array}$ & $\begin{array}{l}2.27(0.64- \\
7.97)\end{array}$ & China & Cohort & 498 & $\begin{array}{l}\text { COVID-19 } \\
\text { patient }\end{array}$ & $\begin{array}{l}\text { COPD comorbid } \\
\text { patients }\end{array}$ & $\begin{array}{l}\text { Non-COPD } \\
\text { comorbid patients }\end{array}$ & $\begin{array}{l}\text { Death in the } \\
\text { hospital }\end{array}$ \\
\hline $\begin{array}{l}\text { Chen, et al., } \\
(2020)\end{array}$ & $\begin{array}{l}1.72(0.80- \\
3.71)\end{array}$ & China & Cohort & 3,309 & $\begin{array}{l}\text { COVID-19 } \\
\text { patient }\end{array}$ & $\begin{array}{l}\text { COPD comorbid } \\
\text { patients male and } \\
\text { female }\end{array}$ & $\begin{array}{l}\text { Male and female } \\
\text { non-COPD } \\
\text { comorbid patients }\end{array}$ & $\begin{array}{l}\text { Death in the } \\
\text { hospital }\end{array}$ \\
\hline Oh, (2021) & $\begin{array}{l}1.56(1.06- \\
2.2)\end{array}$ & South Korea & Cohort & 122,040 & $\begin{array}{l}\text { COVID-19 } \\
\text { patient }\end{array}$ & $\begin{array}{l}\text { COPD comorbid } \\
\text { patients }\end{array}$ & $\begin{array}{l}\text { Non-COPD } \\
\text { comorbid patients }\end{array}$ & $\begin{array}{l}\text { Death in the } \\
\text { hospital }\end{array}$ \\
\hline $\begin{array}{l}\text { Caliskan } \\
(2020)\end{array}$ & $\begin{array}{l}3.213(1.224- \\
8.431)\end{array}$ & Turkey & Cohort & 565 & $\begin{array}{l}\text { COVID-19 } \\
\text { patient }\end{array}$ & $\begin{array}{l}\text { COPD comorbid } \\
\text { patients and smoking }\end{array}$ & $\begin{array}{l}\text { Non-COPD } \\
\text { comorbid patients } \\
\text { and smoking }\end{array}$ & $\begin{array}{l}\text { Death in the } \\
\text { hospital }\end{array}$ \\
\hline $\begin{array}{l}\text { Cetinkal et al., } \\
(2020)\end{array}$ & $\begin{array}{l}0.74(0.30- \\
1.76)\end{array}$ & Turkey & Cohort & 694 & $\begin{array}{l}\text { COVID-19 } \\
\text { patient }\end{array}$ & COPD comorbidities & $\begin{array}{l}\text { Non-COPD } \\
\text { comorbidities }\end{array}$ & $\begin{array}{l}\text { Death in the } \\
\text { hospital }\end{array}$ \\
\hline $\begin{array}{l}\text { Rosa et al., } \\
(2021)\end{array}$ & $\begin{array}{l}1.48(0.99- \\
2.20)\end{array}$ & Italy & Cohort & 1,538 & $\begin{array}{l}\text { COVID-19 } \\
\text { patient }\end{array}$ & $\begin{array}{l}\text { Cardiovascular } \\
\text { comorbidities, } \\
\text { immunosuppression, } \\
\text { COPD }\end{array}$ & $\begin{array}{l}\text { Non-cardiovascular } \\
\text { comorbidities, } \\
\text { immunosuppression } \\
\text {, COPD }\end{array}$ & $\begin{array}{l}\text { Death in the } \\
\text { hospital }\end{array}$ \\
\hline $\begin{array}{l}\text { Borgne et al., } \\
\text { (2021) }\end{array}$ & $\begin{array}{l}3.14\left(0.63^{-}\right. \\
15.66)\end{array}$ & France & Cohort & 287 & $\begin{array}{l}\text { Mild and } \\
\text { severe COVID- } \\
19 \text { patients }\end{array}$ & COPD comorbidities & $\begin{array}{l}\text { Non-COPD } \\
\text { comorbidities }\end{array}$ & $\begin{array}{l}\text { Death in the } \\
\text { hospital }\end{array}$ \\
\hline $\begin{array}{l}\text { Hobbs et al., } \\
(2020)\end{array}$ & $\begin{array}{l}1.58(0.60- \\
3.99)\end{array}$ & $\begin{array}{l}\text { United States } \\
\text { of America }\end{array}$ & Cohort & 502 & $\begin{array}{l}\text { Covid-19 } \\
\text { patient }\end{array}$ & $\begin{array}{l}\text { Cardiovascular } \\
\text { comorbidities, COPD }\end{array}$ & $\begin{array}{l}\text { Non-cardiovascular } \\
\text { comorbidities, } \\
\text { COPD }\end{array}$ & $\begin{array}{l}\text { Death in the } \\
\text { hospital }\end{array}$ \\
\hline $\begin{array}{l}\text { Magleby et al., } \\
(2020)\end{array}$ & $\begin{array}{l}0.65\left(0.23^{-}\right. \\
1.82)\end{array}$ & $\begin{array}{l}\text { United States } \\
\text { of America }\end{array}$ & Cohort & 678 & $\begin{array}{l}\text { COVID-19 } \\
\text { patient }\end{array}$ & $\begin{array}{l}\text { COPD comorbidities, } \\
\text { high, low, moderate } \\
\text { viral load }\end{array}$ & $\begin{array}{l}\text { Non-COPD } \\
\text { comorbidities, high, } \\
\text { low, moderate viral } \\
\text { load }\end{array}$ & $\begin{array}{l}\text { Death in the } \\
\text { hospital }\end{array}$ \\
\hline
\end{tabular}




\section{b. Funnel plot}

In Figure 3, the funnel plot shows an asymmetric distribution of the primary study estimates. The funnel plot indicates that there is a slight publication bias that somewhat overestimates the true effect of COPD comorbidity on hospital mortality for COVID-19 patients (overestimate).

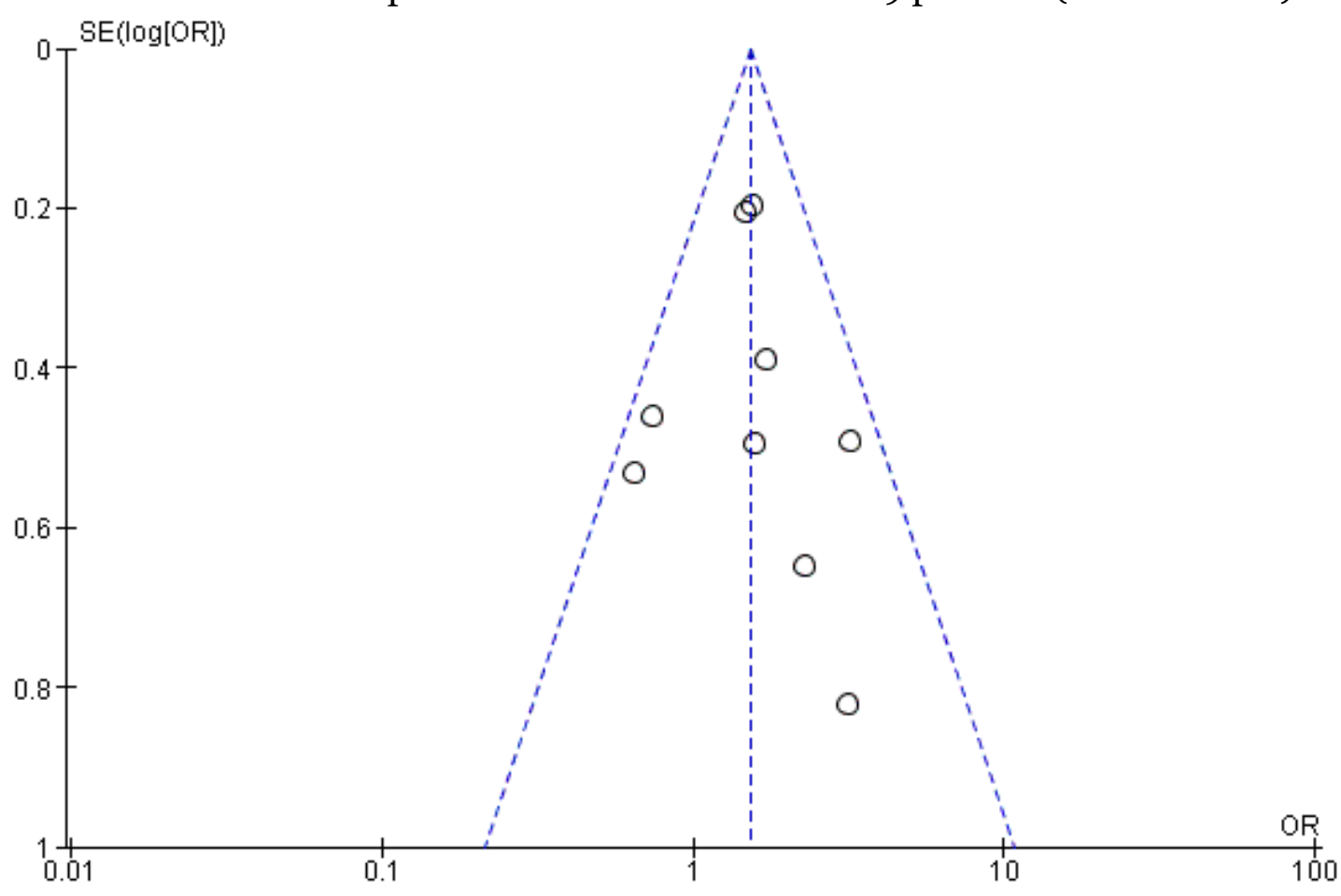

Figure 3. Funnel plot of the relationship between COPD and mortality of COVID-19 patients in hospital

\section{DISCUSSION}

This study includes a study with a systematic review and meta-analysis with the theme of the relationship between COPD comorbidities and COVID-19 mortality in hospitals. The independent variable analyzed was Chronic Obstructive Pulmonary Disease (COPD). The dependent variable studied was the death of COVID-19 patients in the hospital. The results of the primary study conducted by a systematic review and meta-analysis showed an epidemiological study design with a larger sample, different demographic characteristics in both developed and developing countries, thus providing a basis for concluding that COPD comorbidities are associated with mortality of COVID-19 patients in Indonesia. hospital.
An epidemiological study states that one of the risk factors associated with COVID-19 is the comorbid COPD. Other factors that allow the worsening condition of COVID-19 patients are age, gender, and history of pneumonia, as well as comorbid diseases such as hypertension, diabetes mellitus, and cardiovascular disease (Hidayani, 2020).

This systematic review and metaanalysis research uses research that has controlled for confounding factors which can be seen from the inclusion criteria of the previous primary studies used, namely the results of multivariate analysis in the form of adjusted odds ratio (aOR). Confounding factor is a combination of estimates of the relationship between exposure and the disease under study, by other factors that have a relationship, either with 
disease or with exposure. This confounding factor affects the relationship or effect of exposure to the occurrence of the disease estimated by the study is not the same as the actual relationship or effect that occurs in the target population, in other words the study results are not correct (Murti, 2018a)

In this study, there were 9 articles regarding the relationship between COPD comorbidities and mortality of COVID-19 patients in hospitals that were processed using the Revman 5.3 application. The results of the forest plot of research articles with a cohort observational design showed that comorbid COPD was 1.51 times more likely to die than those without COPD and was statistically significant $(\mathrm{aOR}=1.51 ; 95 \%$ $\mathrm{CI}=1.21$ to $1.9 ; \mathrm{p}<0.001)$.

In the analysis, the cohort study design found by the researcher is a prospective cohort study design in all primary studies. The strength of this study is that it confirms that the temporal relationship of exposure precedes disease. Based on this, in its application the researcher prefers the results from cohort studies to be used as evidence based medicine.

The results of the study are supported by the findings by $\mathrm{Hu}$ et. al., (2020) who stated that the mortality of COVID-19 patients in hospital, comorbid COPD was 3.92 times the risk of death $(\mathrm{aOR}=2.27$; $95 \% \mathrm{CI}=0.64$ to $7.97 ; \mathrm{p}=0.202)$. This opinion is reinforced by Hobbs et al. (2020) which states that COVID-19 patients with COPD are 1.58 times at risk of dying in hospital $(\mathrm{aOR}=1.58 ; 95 \% \mathrm{CI}=0.60$ to 3.99 ; $\mathrm{p}=0.34)$

According to Rosa et al. (2021) confirmed that the risk of severe COVID-19 patients with COPD was 1.48 higher than patients without $\mathrm{COPD}(\mathrm{aOR}=1.48 ; 95 \%$ $\mathrm{CI}=0.99$ to $2.21 ; \mathrm{p}=0.056)$. A total of 422 (27\%) patients died while being hospitalized.
Oh (2021) reports that patients with ILD (Interstitial Lung Disease) have a higher risk of COVID-19. Patients with ILD often have symptoms of dyspnea, making it difficult for them to wear a mask, even though wearing a mask is the most protecttive method of preventing COVID-19. Furthermore, this study showed that patients with COPD had a 1.56-fold higher risk of in-hospital death after diagnosis of COVID $-19(\mathrm{aOR}=1.56 ; 95 \% \mathrm{CI}=1.06$ to 2.23; $\mathrm{p}=0.024)$.

\section{AUTHOR CONTRIBUTION}

Pamogsa Daniyar is the main researcher who selects the topic, searches and collects research data. Agus Kristiyanto and Setyo Sri Rahardjo analyzed data and reviewed research documents.

\section{FUNDING AND SPONSORSHIP}

This study is self-funded.

\section{CONFLICT OF INTEREST}

There is no conflict of interest in this study.

\section{ACKNOWLEDGEMENT}

We are very grateful to database providers PubMed, Google Scholar, Science Direct, and BMJ.

\section{REFERENCES}

Alemzadeh-Ansari M (2020). Coronavirus disease 2019 (COVID-19) and cardiovascular events. Res Cardiovascular Med. 9(1): 1. http://dx.doi.org/10.4103/rcm.rcm_9_20.

Hobbs ALV, Turner N, Omer I, Walker MK, Beaulieu RM, Sheikh M, Spires SS, et al. (2020). Risk factors for mortality and progression to severe COVID-19 disease in the Southeast United States (US). Infect Control Hosp Epidemiol. 1-33. https://doi.org/10.1017/ice.2020.1435 . 
Le Borgne P, Solis M, Severac F, Merdji H, Ruch Y, Intern KA, Bayle E, et al. (2021). SARS-CoV-2 viral load in nasopharyngeal swabs in the emergency department does not predict COVID-19 severity and mortality. Acad Emerg Med. 28(3): 306-313. https://doi.org/10.1111/acem.14217.

Brashers VL (2007). Aplikasi klinis patofisiologi pemeriksaan dan manajemen (Clinical applications of pathophysiology examination and management) Edisi 2. Jakarta: EGC Buku Kedokteran.

Caliskan T (2020). Smoking and comorbidities are associated with COVID-19 severity and mortality in 565 patients treated in Turkey. Rev Assoc Med Bras (1992). 66(12): 1679-1684. https://doi.org/10.1590/1806-9282.66.12.1679 .

Center for Evidence Based Management. (2014). Critical Appraisal Checklist for Cross-Sectional Study.

Cen Y, Chen X, Shen Y, Zhang XH, Lei Y, $\mathrm{Xu} \mathrm{C}$, Jiang WR, et al. (2020). Risk factors for disease progression in patients with mild to moderate coronavirus disease 2019-A multicentre observational study, clinical microbiology and infection. Clin Microbiol Infect. 26(9): 1242-1247. https://doi.org/10.1016/j.cmi.2020.0 5.041.

Cetinkal G, Kocas BB, Ser OS, Kilci H, Keskin K, Ozcan SN, Verdi Y, et al. (2020). Assessment of the modified CHA2DS2VASc risk score in predicting mortality in patients hospitalized with COVID-19. Am J Cardiol. 135: 143-149. https://doi.org/10.1016/j.amjcard.2020.08.040.

Chen J, Bai H, Liu J, Chen G, Liao Q, Yang J, Wu P, Wei J, Ma D, et. al. (2020). Distinct clinical characteristics and risk factors for mortality in female COVID 19 inpatients: a sex stratified large scale cohort study in Wuhan, China. Clin Infect Dis. 71(12): 31883195.https://doi.org/10.1093/cid/cia a920.

Hippisley-Cox J, Young D, Coupland C, Channon K, Tan PS, Harrison D, et al. (2020). Risk of severe COVID-19 disease with ACE inhibitors and angiotensin receptor blockers: cohort study including 8.3 million people. Heart. 106(19): 1503-1511. https://doi.org/10.1136/heartjnl-2020-317393.

Cummings MJ, Baldwin MR, Abrams D, Jacobson SD, Meyer BJ, Balough EM, Aaron JG, et al. (2020). Epidemiology, clinical course, and outcomes of critically ill adults with COVID-19 in New York City: a prospective cohort study. The Lancet. 1763-1770. https://doi.org/10.1016/So140-6736(20)31189-2.

De Rosa FG, Palazzo A, Rosso T, Shbaklo N, Mussa M, Boglione L, Borgogno E, et al. (2021). Risk factors for mortality in COVID-19 hospitalized patients in Piedmont, Italy: Results from the Multicenter, Regional, CORACLE Registry. J Clin Med. 10(9): 1951. https://doi.org/10.3390/jcm10091951.

Dixon AE, Peters U (2018). The effect of obesity on lung function. Expert Rev Respir Med. 12(9): 755-767 https://doi.org/10.1080/17476348.2018.1506 331.

Driggin E, Madhavan MV, Bikdeli B, Chuich T, Laracy J, Biondi-Zoccai G, Brown TS, et al. (2020). Cardiovascular considerations for patients, health care workers, and health systems during the COVID-19 pandemic. J Am Coll Cardiol. 75(18): 2352-2371. 75 (18): 2352-2371. https://doi.org/- 
Daniyar et al./ Chronic Obstructive Pulmonary Disease and COVID-19 Mortality

10.1016/j.jacc.2020.03.031.

Elezkurtaj S, Greuel S, Ihlow J, Michaelis EG, Bischoff P, Kunze CA, Sinn BV, Gerhold M, et al. (2021). Causes of death and comorbidities in hospitalized patients with COVID-19. Sci Rep. 11(1): 4263. https://doi.org/10.1038/s41598-021-82862-5.

Haroon S, Subramanian A, Cooper J, Anand A, Gokhale K, Byne N, Dhalla $\mathrm{S}$, et al. (2021). Renin-angiotensin system inhibitors and susceptibility to COVID-19 in patients with hypertension: a propensity score-matched cohort study in primary care. BMC Infect Dis. 21: 262. https://doi.org/10.1186/s12879-021-05951-w.

Hidayani WR (2020). Faktor faktor risiko yang berhubungan dengan COVID 19. (Risk factors associated with COVID 19). Jurnal Untuk Masyarakat Sehat. 4(2): 120-134. doi: 10.52643/jukmas.v4i2.1015.

Hunter JE, Jensen JL, Rodgers R (2014). The control group and meta-analysis. J Methods Meas Soc Sci. 6(1): 3-21. doi: 10.2458/azu_jmmss.v5i1.18302.

Ilmusiana (2019). Peta Dunia. Ilmusiana. https://www.ilmusiana.com/2019/o8 /peta-dunia-hd-2019.html. (diakses 28 Juni 2019)

Junaidin J, Syam Y, Irwan AM (2019). Pengaruh pursed lip breathing dan meniup balon terhadap kekuatan otot pernapasan, saturasi oksigen dan respiratory rate pada pasien PPOK. Jurnal Ilmiah Keperawatan (Scientific Journal of Nursing). 5(1): 31-39. doi: 10.33023/jikep.v5i1.211.

Kemenkes RI (2008). Pedoman pengendalian penyakit paru obstruktif kronik (Guidelines for the control of chronic obstructive pulmonary diseases). Keputusan Menteri Kesehatan Republik Indonesia.
Leung JM, Niikura M, Yang CWT, Sin DD (2020). COVID-19 and COPD. Eur Respir J. 56(2): 2002108. https://doi.org/10.1183/13993003.021082020.

Liu Y, Yang Y, Zhang C, Huang F, Wang F, Yuan J, Wang Z et al. (2020). Clinical and biochemical indexes from 2019nCoV infected patients linked to viral loads and lung injury. Sci China Life Sci. 63(3): 364-374. https://doi.org/10.1007/s11427-020-1643-8.

Magleby R, Lars W, Alex T, Matthew S, Mangala R, Joel P, Para G, et al. (2020). Impact of SARS-CoV-2 viral load on risk of intubation and mortality among hospitalized patients with Coronavirus disease 2019. Clin Infect Dis. ciaa851. https://dx.doi.org/10.1093\%2Fcid\%2Fciaa851.

Mikolajewicz N, Komarova SV (2019). Meta-analytic methodology for basic research: A practical guide. Front Physiol. 10: 203 https://dx.doi.org/10.3389\%2Ffphys.2019.00203.

Mostafaei A, Ghojazadeh M, Hajebrahimi S, Abolhasanpour N, Salehi-Pourmehr H (2021). Clinical presentation of Iranian patients affected with COVID-19: A thousand faces disease. Iran $\mathrm{J}$ Allergy Asthma Immunol. 20(2): 140146. doi: 10.18502/ijaai.v20i2.6047.

Mousavizadeh L, Ghasemi S (2020). Genotype and phenotype of COVID-19: Their roles in pathogenesis. J Microbiol Immunol Infect. 54(2): 159-163 https://doi.org/10.1016/j.jmii.2020.0 3.022 .

Murti B (2018). Prinsip dan metode riset epidemiologi (Principles and methods of epidemiological research). $5^{\text {th }}$ ed. Karanganyar: Program Studi Ilmu Kesehatan Masyarakat.

Nikolakopoulou A (2014). Characteristics of networks of interventions: A descrip- 
tion of a database of 186 published networks. PLoS One. 2014; 9(1): e86754. https://dx.doi.org/10.1371\%2Fjournal.pone.0086754.

Oh TK, Song IA (2021). Impact of Coronavirus Disease-2019 on chronic respiratory disease in South Korea: An NHIS COVID-19 database cohort study. BMC Pulm Med. 21(1): 12. https://doi.org/10.1186/s12890-02001387-1.

Paldam M (2015). Meta-analysis in a nutshell: techniques and general findings. 1-15. doi: 10.5018/economicsejournal.ja.2015-11.

Pranata R, Soeroto Y, Huang I, Lim, Santoso P, Permana, Lukito AA (2020). Effect of chronic obstructive pulmonary disease and smoking on the outcome of COVID-19. Int J Tuberc Lung Dis. 24(8): 838-843. https://doi.org/10.5588/ijtld.20.0278.

Sedgwick P (2013). Meta-analyses: How to read a funnel plot. BMJ. 346: f1342. https://doi.org/10.1136/bmj.f1342.

Shah P, Owens J, Franklin J, Mehta A, Heymann W, Sewell W, Hill J, et al. (2020). Demographics, comorbidities and outcomes in hospitalized Covid19 patients in rural southwest Georgia. Ann Med. 52(7): 354-360. https://doi.org/10.1080/07853890.2020.1 791356.

Siddaway AP, Wood AM, Hedges LV (2018). How to do a systematic review: A best practice guide for conducting and reporting narrative reviews, meta-analyses, and meta-syntheses. Ann Rev Psychol. 70(1): 747770. https://doi.org/10.1146/annurev-psych-010418-102803.

Smith MC, Wrobel JP (2014). Epidemiology and clinical impact of major comorbidities in patients with COPD. Int $\mathrm{J}$ Chron Obstruct Pulmon Dis. 9: 871-
888. https://doi.org/10.2147/copd.s49621.

Somani SS, Richter F, Fuster V, Freitas JK, Naik N, Sigel K, Bottinger EP, et al. (2020). Characterization of patients who return to hospital following discharge from hospitalization for COVID-19. J Gen Intern Med. 35(10): 2838-2844. https://dx.doi.org/10.1007\%2Fs11606-020-06120-6.

Susilo A, Rumende CM, Pitoyo CW, Santoso WD, Yulianti M, Herikurniawan H, Sinto R, et al. (2020). Coronavirus Disease 2019: Tinjauan literatur terkini. Jurnal Penyakit Dalam Indonesia, 7(1): 45. http://dx.doi.org/10.7454/jpdi.v7i1.415.

Viktorova IB, Zimina VN, Kravchenko AV (2020). Chronic obstructive pulmonary disease and HIV-infection. HIV Infect Immunosuppr Dis. 12(4): 2331. doi: $10.22328 / 2077-9828-2020-$ 12-4-23-31.

de Vito A, Geremia N, Fiora V, Princic E, Babudieri S, Madeddu G (2020). Clinical features, laboratory findings and predictors of death in hospitalized patients with COVID-19 in Sardinia, Italy. Eur Rev Med Pharmacol Sci. 24(14): 7861-7868. https://doi.org/10.26355/eurrev_202007_22291.

Walker J, Dolly S, Ng L, Prior-Ong M, Sabapathy K (2020). The role of CPAP as a potential bridge to invasive ventilation and as a ceiling-of-care for patients hospitalized with Covid-19An observational study. PLoS One. 15(12): e0244857. https://doi.org/10.1371/journal.pone.0244857.

Wang, Dawei, Hu Chang, Zhu Fangfang, Zhang Jing, Wang Binbin, Xiang Hiu, Cheng Zhengshun, Xiong Yong, et al. (2020). Clinical characteristics of 138 hospitalized patients with 2019 Novel Coronavirus-infected Pneumonia in 
Wuhan, China. JAMA. 323(11): 10611069. https://doi.org/10.1001/jama.2020.1585.

Woodall GM (2014). Graphical Depictions of Toxicological Data. in Encyclopedia of Toxicology. 786-795. http://dx.doi.org/10.1016/B978-0-12-3864543.01051-4.

World Health Organization (2020). Coronavirus disease 2019 (COVID-19) Situation Report-70. J Intern Med Taiwan. 31(2): 61-66. Available at: https://www.who.int/docs/defaultsource/coronaviruse/situation-reports/20200330-sitrep-70-covid-19.pdf?sfvrsn=7eofe 3 f8_4.

World Health Organization (2020). WHO Director General remark at the media briefing on 2019 nCov. Accessed from https://www.who.int/director-gene$\mathrm{ral} / \mathrm{speeches} /$ detail/who-director- general-s-opening-remarks-at-themedia-briefing-on-covid-4-august2021.

Zhang SY, Lian JS, Hu JH, Zhang XL, Lu YF, Cai H, Gu JQ, et al. (2020). Clinical characteristics of different subtypes and risk factors for the severity of illness in patients with COVID-19 in Zhejiang, China. Infect Dis Poverty 9: 85. https://doi.org/10.1186/s40249-020-00710-6.

Zhou F, Yu T, Du R, Fan G, Liu Y, Liu Z, Xiang J, et al. (2020). Clinical course and risk factors for mortality of adult inpatients with COVID-19 in Wuhan, China. The Lancet. 395(10229): 1054-1062. https://doi.org/10.1016/So140-6736(20)30566-3. 